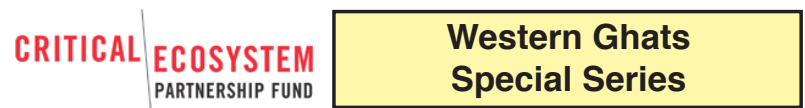

\title{
First record of the genus Tigidia Simon, 1892 (Araneae: Barychelidae) from India with description of three new species from the Western Ghats, India
}

\author{
Manju Siliwal ${ }^{1}$, Neha Gupta ${ }^{2}$, Rajesh V. Sanap ${ }^{3}$, Zeeshan A. Mirza ${ }^{4} \&$ Robert Raven ${ }^{5}$ \\ ${ }^{1}$ Wildlife Information Liaison Development Society, 9-A, Lal Bahadur Colony, Peelamedu, Coimbatore, Tamil Nadu 641004, India \\ ${ }^{2}$ University School of Environment Management, Guru Gobind Indraprastha University, Sector 16-C, Dwarka, New Delhi 110075, India \\ ${ }^{3}$ D-5/2, Marol Police Camp, Andheri (East), Mumbai, Maharashtra 400059, India \\ ${ }^{4}$ Zoology Department, Bhavan's College, Andheri (West), Mumbai, Maharashtra 400058, India \\ ${ }^{5}$ Queensland Museum, Grey Street, PO Box 3300, South Brisbane, 4101, Queensland, Australia \\ Email: ${ }^{1}$ manjusiliwal@gmail.com (corresponding author), ${ }^{2}$ neha_11taurian@rediffmail.com, ${ }^{3}$ rajeshvsanap@gmail.com \\ ${ }^{4}$ snakeszeeshan@gmail.com, ${ }^{5}$ robert.raven@qm.qld.gov.au
}

Date of publication (online): 26 December 2011 Date of publication (print): 26 December 2011 ISSN 0974-7907 (online) | 0974-7893 (print)

Editor: Ansie Dippenaar-Schoeman

\section{Manuscript details:}

Ms \# 02874

Received 13 July 2011

Final received 09 August 2011

Finally accepted 21 October 2011

Citation: Siliwal, M., N. Gupta, R.V. Sanap, Z.A Mirza \& R. Raven (2011). First record of the genus Tigidia Simon, 1892 (Araneae: Barychelidae) from India with description of three new species from the Western Ghats, India. Journal of Threatened Taxa 3(12): 2229-2241.

Copyright: (c) Manju Siliwal, Neha Gupta, Rajesh V. Sanap, Zeeshan A. Mirza \& Robert Raven 2011. Creative Commons Attribution 3.0 Unported License. JoTT allows unrestricted use of this article in any medium for non-profit purposes, reproduction and distribution by providing adequate credit to the authors and the source of publication.

For Author Details, Author Contribution and Acknowledgements see end of this article.
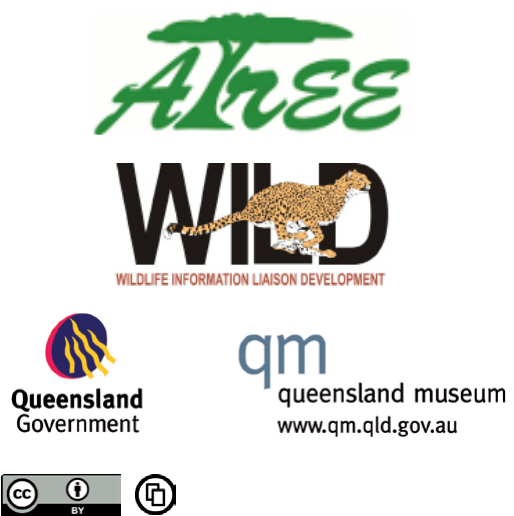

OPEN ACGESS | FREE DOWNLOAD
Abstract: Prior to this study the genus Tigidia Simon, 1892 of the Brush-footed Spider family Barychelidae was represented by eight species endemic to Madagascar and Mauritius Islands. The first occurrence of Tigidia in India is reported here with the description of three new species from the Western Ghats, T. sahyadri sp. nov. from Uttara Kannada District, Karnataka; T. nilgiriensis sp. nov. from Kotagiri, Nilgiri District, Tamil Nadu and T. rutilofronis sp. nov. from Maruthamalai, Coimbatore District, Tamil Nadu. This genus is probably a Gondwana relict. Natural history information is provided for all the species.

Keywords: Araneae, Barychelidae, Gondwana relict, new species, Tigidia, Western Ghats.

\section{INTRODUCTION}

The Brush-footed Spider family Barychelidae is represented worldwide by 44 genera and 303 species (Platnick 2011). Thirteen of these genera have only a single pair of spinnerets (Raven 1994; Dippenaar-Schoeman 2002). Another important generic character of the barychelids is the size of the paired claws, of the 13 two spinneret barychelid genera, there are only three genera having paired tarsal claws I and II very reduced compared

Abbreviations: ALE - anterior lateral eye; AME - anterior median eye; MOQ - median ocular quadrate; MS - Manju Siliwal; NG - Neha Gupta; PLE - posterior lateral eye; PME - posterior median eye; PLS - posterior lateral spinnerets; PMS - posterior median spinnerets; RR - Robert Raven; RS - Rajesh Sanap; STC - Superior or paired tarsal claws; WILD - Wildlife Information Liaison Development Society; ZM - Zeeshan Mirza. Abbreviations used for hairs and spines count are: $d$ - dorsal; fe - femur; $\mathrm{mt}$ - metatarsus; p - prolateral; pa - patella; $r$ - retrolateral; ta - tarsus; ti - tibia; v - ventral.

This article forms part of a special series on the Western Ghats of India, disseminating the results of work supported by the Critical Ecosystem Partnership Fund (CEPF), a joint initiative of l'Agence Française de Développement, Conservation International, the Global Environment Facility, the Government of Japan, the MacArthur Foundation and the World Bank. A fundamental goal of CEPF is to ensure civil society is engaged in biodiversity conservation. Implementation of the CEPF investment program in the Western Ghats is led and coordinated by the Ashoka Trust for Research in Ecology and the Environment (ATREE). 
to claws on legs III and IV viz., Diplothele O. P.Cambridge 1890, Synothele Simon, 1908 and Tigidia Simon, 1892 (Raven 1985). Of these, only Diplothele represented by three species was previously known from India (Siliwal et al. 2009; Platnick 2011). The most closely related genus to Diplothele is considered to be Tigidia.

The genus Tigidia was thought to be endemic to Madagascar and Mauritius Islands where it is represented by eight species (Platnick 2011). All the species of this genus were described a century ago and are known only from their type locality. The genus was established with the description of $T$. mauriciana by Simon (1892) from Mauritius. Tigidia remained monotypic until Benoit (1965) added two genera, Forsythula Pocock, 1903 and Tructicus Strand, 1907, to its synonymy. Further, Raven (1985) also synonymised three more genera (Acropholius Simon, 1902; Cestotrema Simon, 1902; Nossibea Strand, 1907) from Madagascar with Tigidia.

The Western Ghats is known for its rich and endemic fauna being a biodiversity hotspot (Myers et al. 2000). However, the present knowledge of its invertebrate fauna is meager and the region likely supports a wealth of invertebrate fauna which is still unknown (Daniels 2003; Mirza \& Sanap 2010). During surveys in the central Western Ghats of Karnataka, authors (NG and MS) collected a barychelid that had two spinnerets. Initially, it was considered to belong to the Indian genus Diplothele. Diplothele and Tigidia are very close allied genera but Raven (1985) listed two distinct characters to distinguish between them, namely, ocular area wider behind than in front and the presence of preening comb on metatarsi (Image 1). On examination of the specimen under the stereomicroscope it was found that the species had a preening comb and an ocular area wider at the back than in front, indicating the specimens collected from Uttara Kannada belong to the genus Tigidia. Later, two more species were collected from the southern Western Ghats of Tamil Nadu by RS and ZM, which were distinctly different from the specimens from Karnataka. It is possible that this genus occurs throughout the Western Ghats but remained unnoticed due to its vertical trapdoor burrows.

Based on the new distribution pattern Tigidia is probably a Gondwanan relict. Morphologically, the closest genus to Tigidia is an African genus Pisenor,

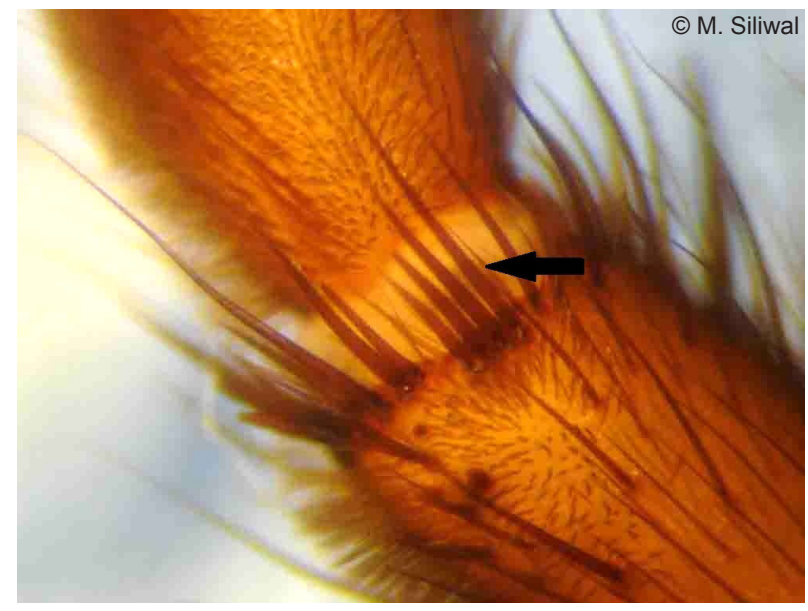

Image 1. Preening comb on metatarsi, a distinguishing character of the genus Tigidia.

which has a similar combination of characters than the Indian genera Diplothele and Tigidia but differs in that Pisenor retains the putatively plesiomorphic character that all paired claws of the legs are the same size; in Tigidia and Diplothele, the paired claws of legs I and II are very small, relatively about half the size of the claws on legs III, IV (Table 1). The 13 barychelid genera with two spinnerets are known from Australia, South Asia and the African subcontinent (Raven 1985; Platnick 2011) seem to be an ideal group to study evolutionary lineage and also to test the Gondwana theory (Datta-Roy \& Karanth 2009; Kunte in press). Based on the present finding, the following hypotheses are proposed: (i) Pisenor is the sister genus of Diplothele and Tigidia; (ii) The genus Tigidia evolved after the Indo-Madagascar plate separated from Africa 160 million years ago; and (iii) Diplothele evolved between 50 to 80 million years ago after the Indian plate separated from Madagascar and collided with the Eurasian plate. Phylogenetic studies will be carried out on Tigidia and other closely allied genera to test and justify the aforesaid theories and hypothesis and those will be published separately.

In the present paper, we report on the occurrence of the genus Tigidia in India, a new addition to the generic spider list for the Indian subcontinent and adding to the list of species, which are common between the African and Indian subcontinents (Gondwanan relicts). We describe three new species, based only on female specimens as no males were sampled during the study (September 2009 to May 2010) and provide notes on the natural history for all the new species. 
Table 1. List of characters distinguishing the three genera Pisenor, Tigidia and Diplothele.

\begin{tabular}{|l|l|l|l|l|}
\hline & Characters & Pisenor & Tigidia & Diplothele \\
\hline 1 & Ocular width front vs. behind & Wider behind than front & Wider behind than front & Behind as wide as in front \\
\hline 2 & Fovea & Straight & Procurved & Procurved \\
\hline 3 & Rastellum & Absent & Present & Present \\
\hline 4 & Preening comb on metatarsi & Absent & Present & Absent \\
\hline 5 & Paired claw sizes leg I-II vs. III-IV & Similar & Much smaller & Much smaller \\
\hline 6 & Teeth on claws & Present & Absent & Absent \\
\hline 7 & Abdomen pattern & Two & Mottled & Mottled \\
\hline 8 & Spinnerets & Two & Two \\
\hline
\end{tabular}

\section{METHODS}

All specimens are deposited at the Wildlife Information Liaison Development Society (WILD) Museum, Coimbatore, Tamil Nadu, India. Measurements of body parts except for the eyes were taken with a Mitutoyo ${ }^{\mathrm{TM}}$ vernier caliper. Eye measurements were done with a calibrated ocular micrometer. All measurements are in millimeters. Spermathecae were dissected and cleared in concentrated lactic acid in a $100^{\circ} \mathrm{C}$ water bath for 15-20 minutes. Total length excludes chelicerae. All illustrations were prepared with the help of a camera lucida attached to a MOTIC ${ }^{\mathrm{TM}}$ and Labomed ${ }^{\mathrm{TM}}$ CSM2 stereomicroscopes by MS \& NG for T. sahyadri sp. nov. and RS for rest of the species. The taxonomic description style is after Siliwal et al. (2009).

\section{TAXONOMY}

\section{Tigidia Simon, 1892}

Forsythula Pocock, 1903: 244; Benoit 1965: 28.

Tructicus Strand, 1907: 550; Benoit 1965: 30.

Cestotrema Simon, 1902: 551; Raven 1985: 112.

Nossibea Strand, 1907: 550; Raven 1985: 113.

Acropholius Simon, 1902: 598; Raven 1985: 112.

Type species: Tigidia mauriciana Simon, 1892, based on a female specimen. The holotype is deposited at Muséum national d'Histoire Naturelle de Paris. Type examined by RR.

Diagnosis: The genus Tigidia resembles the genus Diplothele in having two spinnerets, STC of legs I and II clearly smaller than on legs III and IV (Simon 1892; Raven 1985) and bilobed spermathecae. Tigidia can be distinguished from Diplothele by ocular group clearly wider behind than in front (in Diplothele, the ocular group is almost as wide in front as behind); rastellum on low mound consisting of long, thick spines (in Diplothele, the rastellum is on low mound consisting of long, thick curved spines); preening comb present on metatarsi III-IV (in Diplothele, preening comb absent) (Simon 1892; Raven 1985); cephalic and thoracic width almost same, cephalothorax almost as wide as long (difference between length and width is less than $1.0 \mathrm{~mm})$, whereas in Diplothele, the cephalothorax is clearly longer than wide; legs banded (in Diplothele, legs uniformly brown); main lobe of the spermathecae short (in Diplothele, main lobe of the spermathecae longer and filiform).

Distribution: India, Madagascar and Mauritius Islands.

\section{Tigidia sahyadri sp. nov. Siliwal, Gupta \& Raven (Image 2; Figs. 1-7; Table 2)}

\section{Type material:}

Holotype: female, 3.iv.2010, $15.1243^{\circ} \mathrm{N} \quad \&$ $74.40022^{\circ} \mathrm{E}, 587 \mathrm{~m}$, Kumbharwada, Uttara Kannada, Karnataka, India, coll. N. Gupta, S. Chauhan and Ramesh, WILD-10-ARA-876.

Paratypes: One female, 24.iii.2010, $15.16938^{\circ} \mathrm{N}$ \& $74.63309^{\circ} \mathrm{E}, 534 \mathrm{~m}$, Kulgi, Dandeli WLS, Uttara Kannada, Karnataka, India, coll. N. Gupta, S. Chauhan and Ramesh, WILD-10-ARA-785. Two females, 12.iv.2010, $15.164^{\circ} \mathrm{N} \& 74.47497^{\circ} \mathrm{E}, 616 \mathrm{~m}$, teak plantation, Joida, Uttara Kannda, Karnataka, India, coll. N. Gupta, S. Chauhan and Ramesh, WILD-10ARA-910, WILD-10-ARA-911, two female (WILD10-ARA-1010, WILD-10-ARA-1011), one juvenile (WILD-10-ARA-1012), 19.iv.2010, $15.16373^{\circ} \mathrm{N} \&$ 


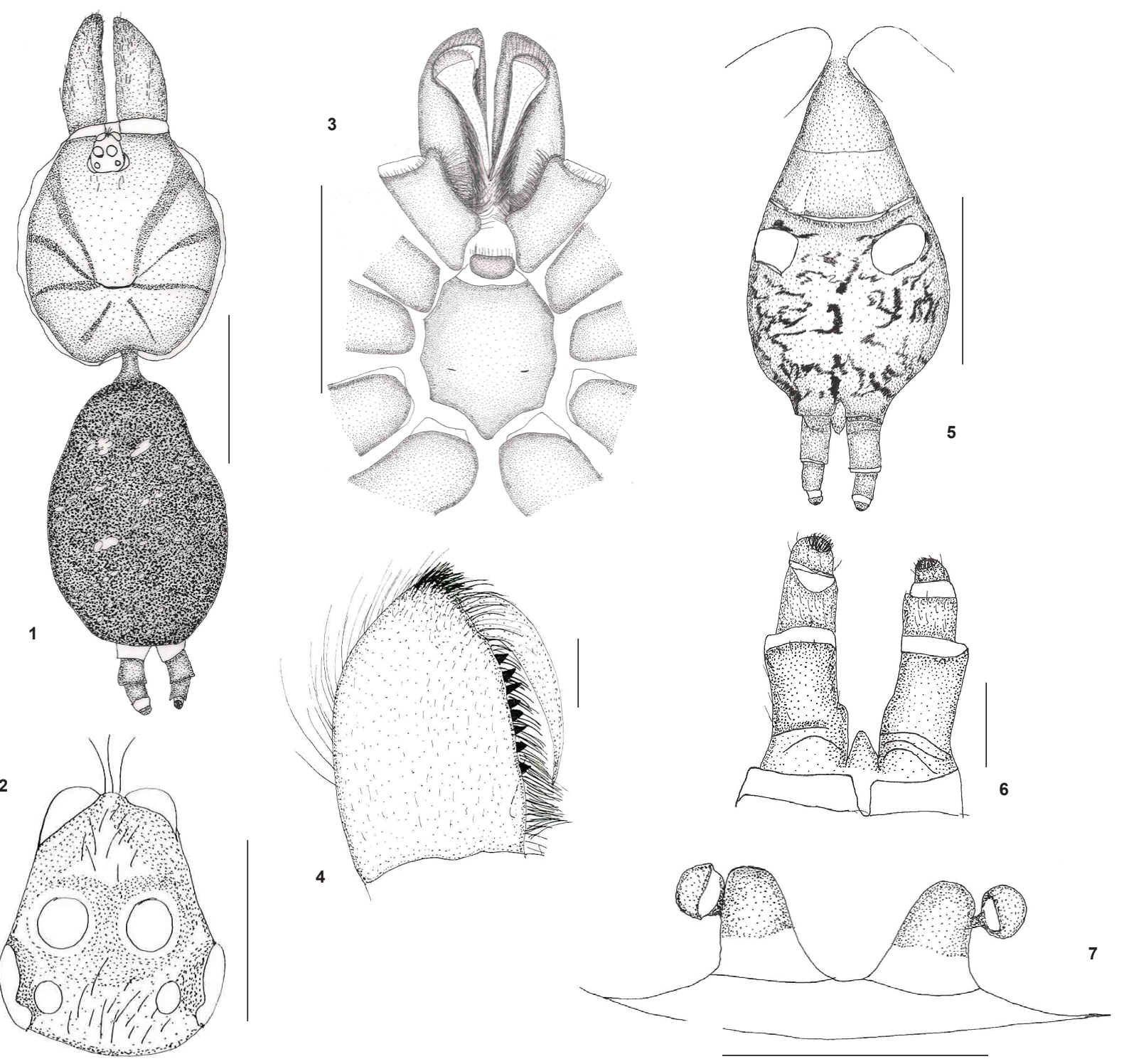

Figures 1-7. Tigidia sahyadri sp. nov. female holotype (WILD-10-ARA-876)

1 - Cephalothorax and abdomen, dorsal view (scale=5.0mm); 2 - Eyes (scale=1.0mm); 3 - Sternum, labium, maxillae and chelicerae, $(\mathrm{scale}=5.0 \mathrm{~mm}) ; 4$ - Chelicerae, prolateral view $(\mathrm{scale}=1.0 \mathrm{~mm}) ; 5$ - Abdomen, ventral view $(\mathrm{scale}=5.0 \mathrm{~mm}) ; 6$ - Spinnerets, ventral view $($ scale $=1.0 \mathrm{~mm}) ; 7$ - Spermathecae $($ scale $=1.0 \mathrm{~mm})$

$74.47442^{\circ} \mathrm{E}, 613 \mathrm{~m}$, mixed forest near forest guest house, Nagoda, near Joida, Uttara Kannada, Karnataka, India, coll. N. Gupta, M. Siliwal and S. Chauhan.

Diagnosis (female): Female differs from other species by the presence of $2-3$ cuspules on the maxillae (T. majori have ca. 10 cuspules), the rastellum consists of numerous spines (cf. T. majori with only a single spine, and T. mauritiana with two spines); main lobe of spermathecae, short and broader at the base, slightly narrowing down at the apex forming a curve; lateral lobe sickle-shaped, emerging almost near the apex $3 / 4^{\text {th }}$ of the main lobe with a distinct constriction at the base.

\section{Etymology}

The species name is a noun in apposition from Sahyadri, another name for the Western Ghats.

\section{Description of holotype female}

Total length 16.44. Carapace 7.82 long, 6.77 wide. Abdomen 8.62 long, 5.92 wide. Spinnerets: PLS, total length 2.24 (1.31 basal, 0.67 middle, 0.26 apical; midwidths $0.86,0.59,0.32$ respectively), 0.43 apart. Legs and palp morphometry is provided in Table 2. 
Table 2. Morphometry of legs and palp of Tigidia sahyadri sp. nov., holotype female, WILD-10-ARA-785. Ranges and mean include all mature specimens (holotype and paratypes) collected from Uttara Kannada. Measurements in $\mathrm{mm}$. ( $\pm 0.02 \mathrm{~mm})$.

\begin{tabular}{|c|c|c|c|c|c|c|c|c|c|c|c|c|c|c|c|}
\hline & \multicolumn{3}{|c|}{ Leg I } & \multicolumn{3}{|c|}{ Leg II } & \multicolumn{3}{|c|}{ Leg III } & \multicolumn{3}{|c|}{ Leg IV } & \multicolumn{3}{|c|}{ Palp } \\
\hline & $\begin{array}{c}\text { WILD- } \\
785\end{array}$ & $\begin{array}{l}\text { Range } \\
(n=5)\end{array}$ & $\begin{array}{c}\text { Mean } \pm \\
\text { SD }\end{array}$ & $\begin{array}{l}\text { WILD- } \\
785\end{array}$ & $\begin{array}{l}\text { Range } \\
(n=5)\end{array}$ & $\begin{array}{c}\text { Mean } \pm \\
\text { SD }\end{array}$ & $\begin{array}{l}\text { WILD- } \\
785\end{array}$ & $\begin{array}{l}\text { Range } \\
(n=5)\end{array}$ & $\begin{array}{c}\text { Mean } \pm \\
\text { SD }\end{array}$ & $\begin{array}{c}\text { WILD- } \\
785\end{array}$ & $\begin{array}{l}\text { Range } \\
(n=5)\end{array}$ & $\begin{array}{c}\text { Mean } \pm \\
\text { SD }\end{array}$ & $\begin{array}{c}\text { WILD- } \\
785\end{array}$ & $\begin{array}{l}\text { Range } \\
(n=5)\end{array}$ & $\begin{array}{l}\text { Mean } \pm \\
\text { SD }\end{array}$ \\
\hline Femur & 4.64 & $\begin{array}{l}3.09- \\
4.64\end{array}$ & $\begin{array}{c}3.94 \pm \\
0.58\end{array}$ & 4.27 & $\begin{array}{c}2.92- \\
4.27\end{array}$ & $\begin{array}{c}3.72 \pm \\
0.56\end{array}$ & 3.74 & $\begin{array}{l}2.58- \\
3.74\end{array}$ & $\begin{array}{c}3.29 \pm \\
0.46\end{array}$ & 5.16 & $\begin{array}{l}3.91- \\
5.17\end{array}$ & $\begin{array}{c}4.708 \pm \\
0.55\end{array}$ & 3.43 & $\begin{array}{c}2.42- \\
3.49\end{array}$ & $\begin{array}{c}3.09 \pm \\
0.45\end{array}$ \\
\hline Patella & 3.18 & $\begin{array}{l}2.44- \\
3.38\end{array}$ & $\begin{array}{c}2.94 \pm \\
0.39\end{array}$ & 3.27 & $\begin{array}{l}2.1- \\
3.27\end{array}$ & $\begin{array}{c}2.78 \pm \\
0.47\end{array}$ & 2.53 & $\begin{array}{l}1.72- \\
2.53\end{array}$ & $\begin{array}{c}2.20 \pm \\
0.33\end{array}$ & 3.36 & $\begin{array}{l}2.21- \\
3.36\end{array}$ & $\begin{array}{c}2.89 \pm \\
0.45\end{array}$ & 2.47 & $\begin{array}{l}1.72- \\
2.47\end{array}$ & $\begin{array}{c}2.18 \pm \\
0.32\end{array}$ \\
\hline Tibia & 3.01 & $\begin{array}{l}1.98- \\
3.01\end{array}$ & $\begin{array}{c}2.58 \pm \\
0.39\end{array}$ & 2.76 & $\begin{array}{l}1.75- \\
2.76\end{array}$ & $\begin{array}{c}2.43 \pm \\
0.43\end{array}$ & 1.89 & $\begin{array}{l}1.32- \\
1.89\end{array}$ & $\begin{array}{l}1.71 \pm \\
0.23\end{array}$ & 3.89 & $\begin{array}{l}2.81- \\
3.89\end{array}$ & $\begin{array}{c}3.44 \pm \\
0.44\end{array}$ & 1.65 & $\begin{array}{l}1.34- \\
1.88\end{array}$ & $\begin{array}{l}1.59 \pm \\
0.24\end{array}$ \\
\hline Metatarsus & 2.16 & $\begin{array}{l}1.32- \\
2.16\end{array}$ & $\begin{array}{l}1.83 \pm \\
0.35\end{array}$ & 2.01 & $\begin{array}{l}1.2- \\
2.05\end{array}$ & $\begin{array}{l}1.77 \pm \\
0.37\end{array}$ & 2.37 & $\begin{array}{l}1.67- \\
2.37\end{array}$ & $\begin{array}{c}2.07 \pm \\
0.29\end{array}$ & 4.0 & $\begin{array}{l}3.26- \\
4.22\end{array}$ & $\begin{array}{c}3.82 \pm \\
0.40\end{array}$ & - & - & - \\
\hline Tarsus & 1.50 & $\begin{array}{l}1.13- \\
1.52\end{array}$ & $\begin{array}{l}1.41 \pm \\
0.16\end{array}$ & 1.47 & $\begin{array}{l}1.13- \\
1.68\end{array}$ & $\begin{array}{l}1.45 \pm \\
0.20\end{array}$ & 1.44 & $\begin{array}{l}1.09- \\
1.54\end{array}$ & $\begin{array}{l}1.34 \pm \\
0.19\end{array}$ & 1.73 & $\begin{array}{l}1.41- \\
1.83\end{array}$ & $\begin{array}{l}1.66 \pm \\
0.17\end{array}$ & 2.49 & $\begin{array}{l}1.31- \\
2.49\end{array}$ & $\begin{array}{c}2.14 \pm \\
0.48\end{array}$ \\
\hline Total & 14.49 & $\begin{array}{l}9.96- \\
14.49\end{array}$ & $\begin{array}{c}12.68 \pm \\
1.83\end{array}$ & 13.78 & $\begin{array}{c}9.1- \\
13.78\end{array}$ & $\begin{array}{c}12.15 \pm \\
1.99\end{array}$ & 11.97 & $\begin{array}{l}8.38- \\
11.97\end{array}$ & $\begin{array}{c}10.61 \pm \\
1.45\end{array}$ & 18.14 & $\begin{array}{l}13.75- \\
18.14\end{array}$ & $\begin{array}{c}16.51 \pm \\
1.91\end{array}$ & 10.04 & $\begin{array}{l}6.79- \\
0.21\end{array}$ & $\begin{array}{c}8.99 \pm \\
1.40\end{array}$ \\
\hline \multicolumn{16}{|c|}{ Midwidth } \\
\hline Femur & 1.51 & $\begin{array}{l}1.11- \\
1.51\end{array}$ & $\begin{array}{l}1.33 \pm \\
0.17\end{array}$ & 1.68 & $\begin{array}{l}1.06- \\
1.68\end{array}$ & $\begin{array}{l}1.46 \pm \\
0.25\end{array}$ & 1.85 & $\begin{array}{l}1.3- \\
1.85\end{array}$ & $\begin{array}{l}1.63 \pm \\
0.23\end{array}$ & 1.7 & $\begin{array}{c}1.26- \\
1.7\end{array}$ & $\begin{array}{l}1.42 \pm \\
0.17\end{array}$ & 1.08 & $\begin{array}{l}0.68- \\
1.08\end{array}$ & $\begin{array}{c}0.95 \pm \\
0.18\end{array}$ \\
\hline Tibia & 1.51 & $\begin{array}{l}1.17- \\
1.59\end{array}$ & $\begin{array}{c}1.40 \pm \\
0.16\end{array}$ & 1.46 & $\begin{array}{l}1.11- \\
1.46\end{array}$ & $\begin{array}{l}1.30 \pm \\
0.14\end{array}$ & 1.46 & $\begin{array}{l}1.1- \\
1.46\end{array}$ & $\begin{array}{c}1.28 \pm \\
0.16\end{array}$ & 1.36 & $\begin{array}{l}1.1- \\
1.36\end{array}$ & $\begin{array}{c}1.24 \pm \\
0.12\end{array}$ & 1.31 & $\begin{array}{l}1.07- \\
1.98\end{array}$ & $\begin{array}{l}1.37 \pm \\
0.36\end{array}$ \\
\hline
\end{tabular}

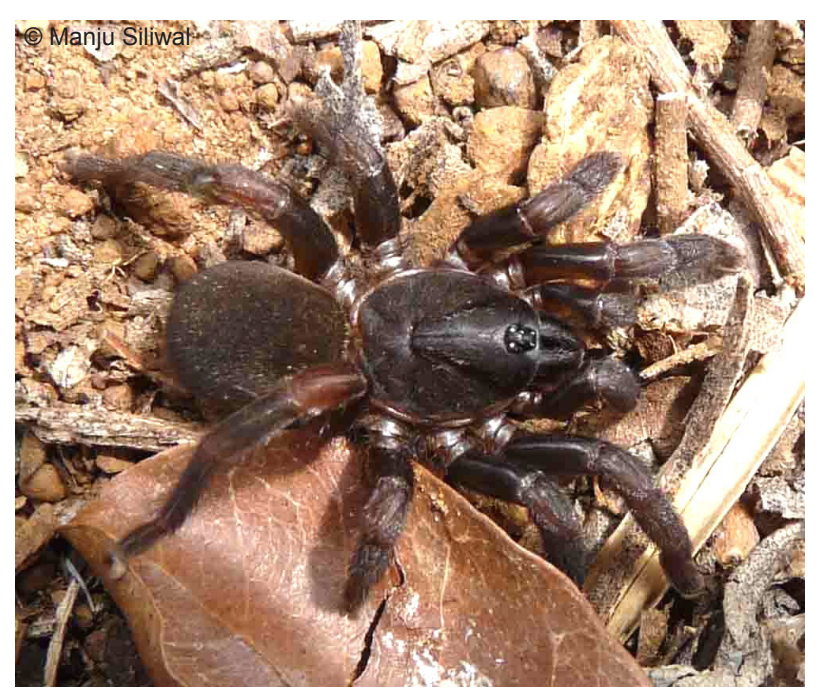

Image 2. Tigidia sahyadri sp. nov.

Colour in life (Image 2): Carapace blackish-brown; legs and palp light brown with complete blackishbrown annulations/bands on proximal half of tibia and $3 / 4$ of femur, metatarsi and tarsi. Abdomen light brown with blackish-brown mottled marking on dorsal to lateral sides. Ventral side, light brown, mottled with small black spots between spinnerets and book lungs. Colour in alcohol paler than fresh specimen.

Carapace covered with blackish-brown and short golden curved hairs; hairs more concentrated along interstrial ridges, intermixed with few black bristles on caput. Bristles: nine long on caput in mid-dorsal line; four long, four short anteromedially; eight long, several short between PME; two long, one short on clypeus edge. Fovea deep, slightly procurved (Fig. 1). Two glabrous bands emerging from fovea and passing on either side of caput.

Eyes (Fig. 2): Group occupies 0.27 of head-width; ocular group: front width, midwidth, back width, and total length, $0.71,1.03,1.23,1.30$ respectively. Anterior row strongly procurved, posterior row straight; posterior eyes opaque, rest transparent. MOQ square, width 0.75 , length 0.70 . Diameter of AME 0.25, ALE 0.29, PME 0.11, PLE 0.35. Eye interspaces: AME-AME 0.11, AME-ALE 0.09, ALE-ALE 0.07, PME-PLE adjacent, PME-PME 0.49, ALE-PLE 0.47 .

Chelicerae (Figs. 3-4): 4.34 long. Prolateral face glabrous, yellowish-orange with few short hairs; eight promarginal cheliceral teeth and 18 basomesal teeth in 2-3 parallel lines; rastellum on low mound, consists of ca. 50 short thick curved spines, with 37 on mound and 12 in anterior line, several normal pointed thin spines on dorsal, and vertical face and up; dorsally with two glabrous longitudinal bands.

Labium (Fig. 3): 0.86 wide, 0.52 long; labiosternal groove broad with two sigilla joined medially. Cuspules absent.

Maxillae (Fig. 3): 2.24 long in front, 2.95 long in 
back, 1.47 wide; $2-3$ cuspules on inner angle. Posterior heel slightly produced, anterior lobe distinct.

Sternum (Fig. 3): 3.76 long, 3.22 wide. Covered with hairs and bristles. Sigilla indistinct.

Legs: Brown, moderately hairy; femora III and tibiae I thicker than rest; all legs of similar thickness; preening comb on ventrolateral metatarsi III and IV; coxae IV widest; two longitudinal glabrous bands on femora, patellae and tibiae (very prominent on patellae); leg formula 4123 .

Spines: Leg III: $p a, p=2 ; \mathrm{ti}, \mathrm{p}=1 ; \mathrm{mt}, \mathrm{p}=2, \mathrm{~d}=1, \mathrm{v}=8$. Leg IV: $m t, p=2, d=1, v=8$.

Scopula: Ta: I-II, full, thick, lateroventral, divided with thin long hairs for length, many normal hairs intermixed with scopulae at base; III-IV, full, lateroventrally divided with 6-7 rows of spines over length. Mt III: well developed scopulae on distal half; III-IV, few scopuliform hairs intermixed with bristles on distal $1 / 4$.

Trichobothria: ta: I, 9-13 clavate, 10-12 long, six short filiform; II, 5-10 clavate, 8-9 long, six short filiform; III, eight clavate, six each long and short filiform; IV, 7 clavate, eight long and six short filiform; palp, 10-12 clavate, 9-11 long, six short filiform. Mt: I, eight long and short; II, 10 long and short; III, 14 long and short; IV, 18 long and short; palp, 11 long and short. Clavate trichobothria confined to proximal half of ta. Short filiform confined to mid-dorsal distal half in a single row, long filiform in V-shaped pattern confined to distal half on ta. Mt, only filiform in curved single row in $2 / 3$ length.

Claws: Claw tufts on all legs and palp. All claws edentate, claws of legs I and II clearly smaller than on legs III and IV.

Abdomen (Figs. 1, 5): Yellowish-cream with heavily mottled (brown patches) on dorsal and lateral, uniformly covered with short brown hairs intermixed with a few black bristles; ventral side, yellowish-cream with brown spots scattered all over, uniformly covered with long and short brown hairs.

Spinnerets (Fig. 6): PMS absent. PLS, apical segment dome-shaped. Covered with golden brown hairs.

Spermathecae (Fig. 7): Paired, bilobed. Main lobe, short and broader at the base, slightly narrowing down at the curving apex; lateral lobe sickle-shaped, emerging almost near apex $3 / 4^{\text {th }}$ of main lobe with a distinct constriction at base.

\section{Variations}

Total length: $10.64-16.44(14.53 \pm 2.49)$. Carapace: 5.57-7.82 (6.81 \pm 0.89$)$ long, 4.71-6.77 (5.94 \pm 0.85$)$ wide; Chelicerae: $2.66-4.34$ (3.45 \pm 0.77$)$ long, 7-8 promarginal and 15-20 basomesal teeth in 2-3 lines, 16-38 rastellum spines on mound, 12-34 in anterior line total ca. 50. Bristles: 9-14 mid-dorsal and 4-6 anteromedial bristles on caput. 4-8 long, several short bristles between PME. Two long, 1-2 short bristles on clypeus edge. Eyes interspaces: AME diameter $0.18-0.27$ (0.22 \pm 0.04$)$, ALE diameter 0.21-0.31 $(0.27 \pm 0.04)$, PME diameter 0.1-0.11 (0.11 \pm 0.01$)$, PLE diameter $0.3-0.45(0.35 \pm 0.06)$. AME-AME distance: $0.05-0.7(0.22 \pm 0.27)$, AME-ALE distance: 0.09-0.29 (0.17 \pm 0.09$)$, ALE-ALE distance: 0.06$0.4(0.17 \pm 0.14)$, PME-PLE adjacent, PME-PME: 0.33-0.49 (0.44 \pm 0.07$)$, ALE-PLE: 0.24-0.47 (0.35 $\pm 0.09)$.

Eyes: Head-width occupied $0.27-0.28$ (0.27 \pm $0.00)$. Eye width: $0.95-1.25(1.14 \pm 0.13)$, head-width 3.46-4.63 (4.18 \pm 0.48$)$. Ocular group: $1.05-1.3$ (1.19 $\pm 0.10)$ long, front width 0.57-0.84 (0.72 \pm 0.11$)$, midwidth $0.71-1.03(0.89 \pm 0.14)$, back width 0.95 $1.25(1.14 \pm 0.13)$. Difference between front width and back width: $0.38-0.52(0.42 \pm 0.06)$. MOQ: 0.51-0.7 $(0.58 \pm 0.08)$ long, front width $0.57-0.75(0.70 \pm 0.08)$, back width $0.57-0.75(0.70 \pm 0.08)$. Labium: $0.47-0.6$ $(0.54 \pm 0.06)$ long, 0.85-1.01 (0.90 \pm 0.07$)$ wide. Sternum: 2.66-3.76 (3.30 \pm 0.50) long, 2.31-3.22 $(2.77 \pm 0.41)$ wide. Maxillae: $1.65-2.24(1.89 \pm 0.27)$ long in front, 2.22-2.95 (2.61 \pm 0.30$)$ long in back, $1.03-1.56(1.29 \pm 0.22)$ wide; cuspules $2-4$. Spines: $\mathrm{mt}$ IV $p=2-3, v=4-8$. Trichobothria: Leg I: 8-13 clavate, 6-8 short, 9-12 long in three rows on ta; leg II: 5-12 clavate, 6-8 short, 8-9 long in three rows on ta; leg III: 6-8 clavate, 5-7 short, 6-9 long in three rows on ta; leg IV: 7-8 clavate, 6-7 long, 6-9 long in three rows on ta; palp: 8-12 clavate, 5-7 short, 8-11long in 3 rows. Abdomen: $5.07-8.95$ (7.73 \pm 1.66$)$ long, 3.68$6.7(5.35 \pm 1.16)$ wide. Spinnerets: PLS, 0.87-1.78 $(1.33 \pm 0.32)$ basal, $0.45-0.67(0.55 \pm 0.11)$ middle, $0.16-0.4(0.25 \pm 0.09)$ apical; midwidths, 0.62-0.86 $(0.73 \pm 0.11), 0.48-0.62(0.53 \pm 0.07), 0.23-0.41(0.30$ $\pm 0.07)$ respectively; $1.59-2.85(2.13 \pm 0.47)$ total length. Distance between PLS-PLS, 0.17-0.43 (0.26 $\pm 0.10)$. 


\section{Natural History}

The burrows of Tigidia sahyadri sp. nov. were found in areas with open canopy (less than 40\%) and fairly good amount of leaf litter (50-80\%), in different habitats including teak plantations, semi-evergreen, mixed and deciduous forests. Most of the burrows found were in closed canopy/shaded area, covered with leaf litter and usually were near or at the base of tree trunk/shrubs, where the soil was a little soft because of the roots. All the burrows found occurred on vertical flat or gentle slopes (less than $15^{\circ}$ ) of forest floors and were located only while clearing the leaf litter with the help of a broom. The distribution of burrows shows no pattern. Burrows were located in March and April, during which all females were found with 10-14 spiderlings. No males were found during this period.

Burrows of $T$. sahyadri sp. nov. were simple, short, silken tube-like chambers, slightly wider at the base bulb-shaped. The entrance of the burrow was closed with a wafer-thin, circular, hinged trapdoor. The hinged door was lined with a thin layer of silk on the under surface; the outer surface was covered with dry leaf litter and soil particles, making it well camouflaged and unnoticeable when the door was closed. These trapdoors were continuous with the tube for nearly one-third of its circumference; it seems that the spider cuts the door from a silken tube rather than constructing it separately and attaching it to the entrance of the burrow. Most of the burrows found during the survey had only a single entrance, except for one. In that one, a Y-shaped or forked burrow was noticed, where two chambers with separate entrances led to a common chamber. Both the entrances of the burrow had a hinged door and these two doors were separated by a distance of almost double the door diameter.

The mean diameter of the trapdoors of the burrows $(\mathrm{n}=6)$ excavated was $15 \mathrm{~mm}$ (range: $8-22 \mathrm{~mm}$ ). Like most of the barychelid burrows known (Raven 1994), burrows of Tigidia sahyadri sp. nov. were not very deep. The mean depth of burrows was $68 \mathrm{~mm}$ (range: 50-80 mm). The burrow with two entrances had each individual chamber $25 \mathrm{~mm}$ long, which was nearly one-third of the total length of the burrow $(75 \mathrm{~mm})$.

When a burrow was disturbed, the spider hid deep inside the burrow and remained there until the burrow was fully excavated. This behaviour could be related to parental care as all the females were with spiderlings and probably remained in the burrow to guard their offspring. Moreover, this behavior is also reported in many species of barychelids and idiopids (Raven 1994) but it is not mentioned whether such behaviour is corelated with nesting of young spiders.

\section{Tigidia nilgiriensis sp. nov. Sanap, Mirza \& Siliwal (Image 3; Figs. 8-12; Table 3)}

\section{Type specimens}

Holotype: female, 28.i.2011, $11^{0} 27^{\prime} 1.56^{\prime \prime} \mathrm{N}$, \& 76056'34.38'E, 1737m, Kotagiri, Nilgiri District, Tamil Nadu, India coll. Rajesh Sanap, WILD-11ARA-1110.

\section{Diagnosis (female)}

The female resembles those of T. sahyadri sp. nov. in the number of cuspules on the maxillae, and the rastellum consists of numerous spines but it differs from $T$. majori by having only two cuspules on the maxillae (T. majori have ca. 10 cuspules), a rastellum consists of numerous spines (cf. T. majori with a single spine and T. mauritiana with two spines); it differs from $T$. sahyadri sp. nov. by the lateral lobe of the spermathecae being balloon-like at 2/3 distal end with constriction at base (in T. sahyadri sp. nov., lateral lobe sickle-shape, emerging almost near the apex/ $3 / 4^{\text {th }}$ of the main lobe with a distinct constriction at the base).

\section{Etymology}

The species name refers to the Nilgiri Hills within

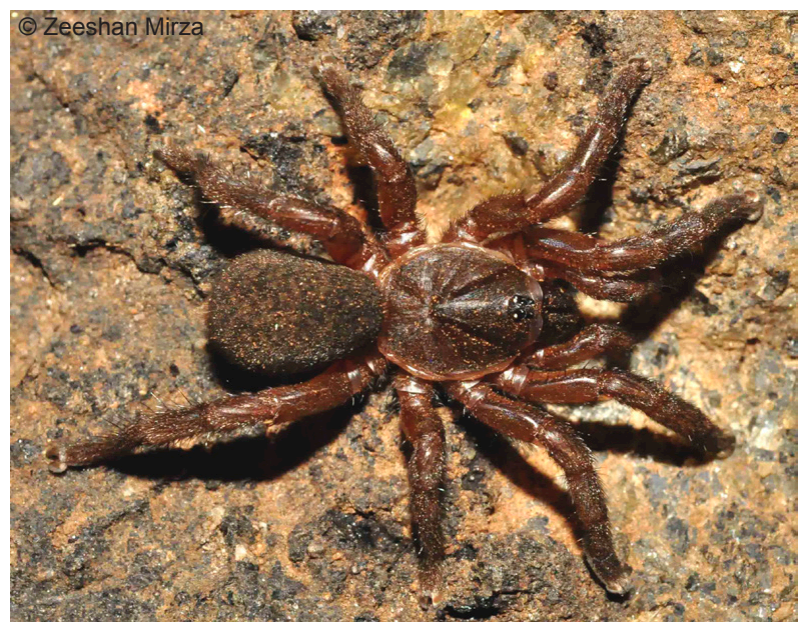

Image 3. Tigidia nilgiriensis sp. nov. 

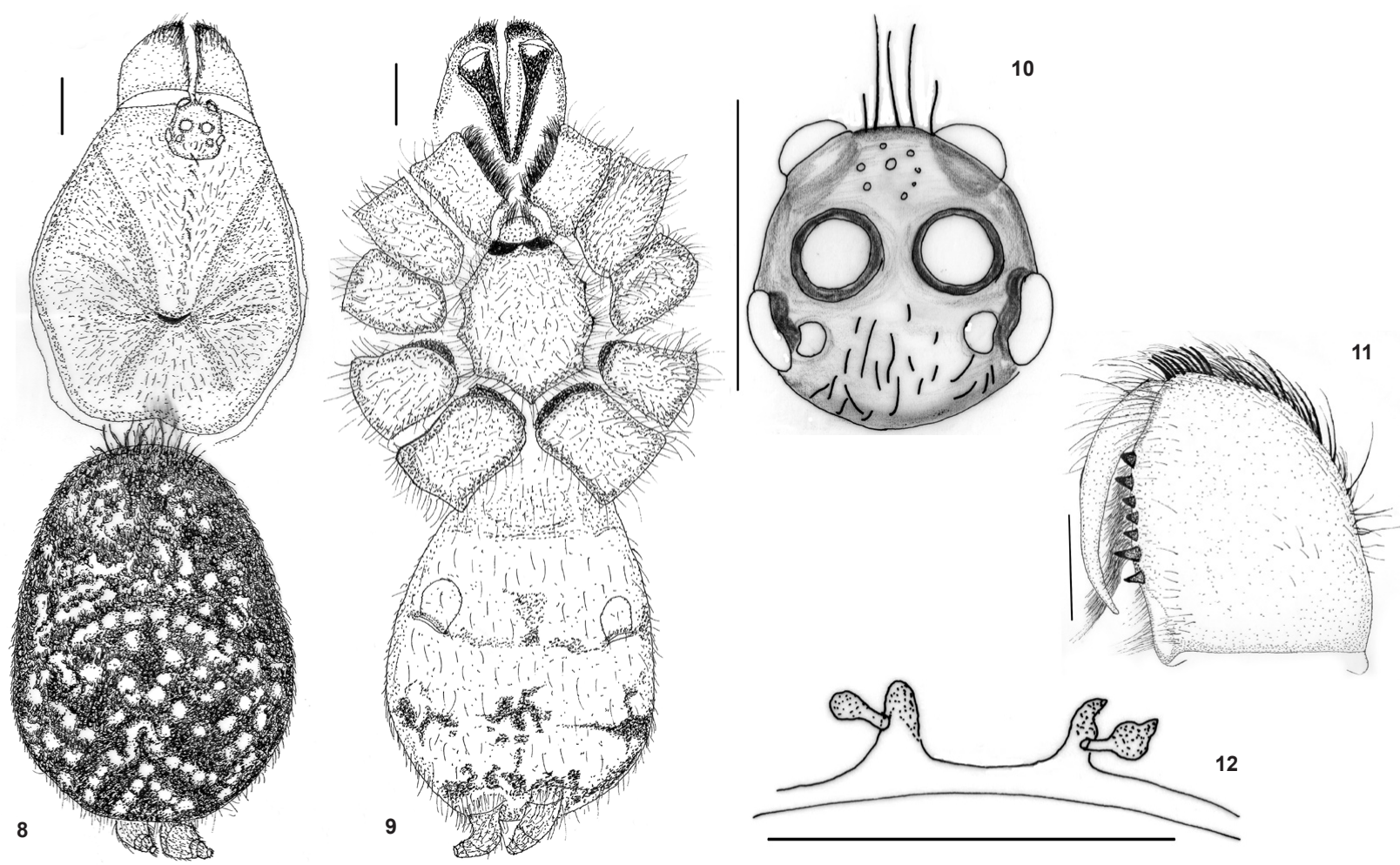

Figures 8-12. Tigidia nilgiriensis sp. nov. female holotype (WILD-11-ARA-1110)

8 - Carapace and abdomen, dorsal view (scale $=1.0 \mathrm{~mm}) ; 9$ - Sternum, labium, maxilla and abdomen, ventral view $(\mathrm{scale}=1.0 \mathrm{~mm})$; 10 - Eyes $($ scale=1.0mm); 11 - Chelicerae, prolateral view $($ scale $=1.0 \mathrm{~mm}) ; 12$ - Spermathecae $($ scale $=1.0 \mathrm{~mm})$

Table 3. Morphometry of legs and palp of T. nilgiriensis sp. nov. holotype female (WILD-11-ARA-1110) and T. rutilofronis sp. nov. holotype female (WILD-11-ARA-1111) and paratype female (WILD-11-ARA-1112). Measurements in $\mathrm{mm}$. $( \pm 0.02 \mathrm{~mm})$.

\begin{tabular}{|c|c|c|c|c|c|c|c|c|c|c|c|c|c|c|c|}
\hline & \multicolumn{3}{|c|}{ Leg I } & \multicolumn{3}{|c|}{ Leg II } & \multicolumn{3}{|c|}{ Leg III } & \multicolumn{3}{|c|}{ Leg IV } & \multicolumn{3}{|c|}{ Palp } \\
\hline & $\begin{array}{c}\text { WILD- } \\
1110\end{array}$ & $\begin{array}{c}\text { WILD- } \\
1111\end{array}$ & $\begin{array}{c}\text { WILD- } \\
1112\end{array}$ & $\begin{array}{c}\text { WILD- } \\
1110\end{array}$ & $\begin{array}{c}\text { WILD- } \\
1111\end{array}$ & $\begin{array}{c}\text { WILD- } \\
1112\end{array}$ & $\begin{array}{c}\text { WILD- } \\
1110\end{array}$ & $\begin{array}{c}\text { WILD- } \\
1111\end{array}$ & $\begin{array}{c}\text { WILD- } \\
1112\end{array}$ & $\begin{array}{c}\text { WILD- } \\
1110\end{array}$ & $\begin{array}{l}\text { WILD- } \\
1111\end{array}$ & $\begin{array}{c}\text { WILD- } \\
1112\end{array}$ & $\begin{array}{c}\text { WILD- } \\
1110\end{array}$ & $\begin{array}{c}\text { WILD- } \\
1111\end{array}$ & $\begin{array}{c}\text { WILD- } \\
1112\end{array}$ \\
\hline Femur & 2.44 & 5.52 & 1.18 & 2.58 & 1.52 & 1.22 & 2.44 & 1.44 & 1.20 & 3.34 & 2.42 & 1.42 & 2.12 & 1.98 & 1.68 \\
\hline Patella & 2.10 & 3.08 & 1.52 & 2.04 & 2.20 & 1.32 & 1.58 & 2.32 & 1.42 & 1.90 & 5.30 & 2.98 & 1.42 & 1.68 & 1.04 \\
\hline Tibia & 1.72 & 3.40 & 2.06 & 1.68 & 2.84 & 1.72 & 1.30 & 2.38 & 1.18 & 2.30 & 4.20 & 2.86 & 1.14 & 2.34 & 1.34 \\
\hline Metatarsus & 1.04 & 2.52 & 2.02 & 1.12 & 3.72 & 1.94 & 1.34 & 2.68 & 1.54 & 2.24 & 3.58 & 1.92 & - & - & - \\
\hline Tarsus & 0.78 & 1.52 & 3.30 & 1.00 & 5.06 & 2.86 & 1.04 & 4.06 & 2.46 & 1.28 & 6.22 & 3.86 & 1.32 & 3.74 & 2.44 \\
\hline Total & 8.08 & 16.04 & 10.08 & 8.42 & 15.34 & 9.06 & 7.7 & 12.88 & 7.8 & 11.06 & 21.72 & 13.04 & 6 & 9.74 & 6.5 \\
\hline \multicolumn{16}{|c|}{ Midwidth } \\
\hline Femur & 0.92 & 1.82 & 1.08 & 1.00 & 1.98 & 1.26 & 1.12 & 2.10 & 1.28 & 1.02 & 1.96 & 1.28 & 0.70 & 1.36 & 0.78 \\
\hline Tibia & 0.92 & 1.62 & 1.00 & 0.94 & 1.38 & 0.90 & 0.92 & 1.52 & 0.86 & 0.98 & 1.42 & 0.92 & 0.80 & 1.40 & 0.92 \\
\hline
\end{tabular}

which the type locality is located.

\section{Description}

Total length 9.86. Carapace 4.32 long, 3.46 wide. Abdomen 5.54 long, 3.82 wide. Spinnerets: PLS, total length 1.06 (0.62 basal, 0.30 middle, 0.14 apical; midwidths $0.38,0.26,0.18$ respectively), 0.42 apart. Legs and palp morphometry is provided in Table 3.

Colour in life (Image 3): Carapace dark brown. Abdomen dark brown with faint yellow spots on dorsal and lateral sides (Fig. 8); ventral side yellowish-brown with sparsely mottled (dark brown) on mid-ventral and 
highly mottled towards posterior end near spinnerets (Fig. 9). Colour in alcohol paler and abdominal markings distinct and more visible on dorsal and lateral abdomen.

Carapace covered with blackish-brown curved hairs; hairs more concentrated along interstrial ridges, intermixed with black short and long bristles on caput. Bristles: two foveal; 10 long on caput in mid-dorsal line, six between anterior eyes, five long and short on clypeus edge; 19 between posterior eyes. Fovea deep, procurved with curved ends. Several hairs between PME and ALE. Glabrous bands radiating from fovea, very prominent along sides of caput.

Eyes (Fig. 10): Ocular group front width 0.54, midwidth 0.50 , back width 0.70 , length 0.70 . Anterior row strongly procurved, posterior row straight, PME opaque, rest transparent. MOQ front width 0.28 , back width 0.32 , length 0.22 . Diameter of AME 0.12, ALE 0.12, PME 0.04, PLE 0.14. Eye interspaces: AMEAME 0.08, AME-ALE 0.14, ALE-ALE 0.08, PMEPLE adjacent, PME-PME 0.18, ALE-PLE 0.16.

Chelicerae (Fig. 11): 2.40 long. Prolateral face glabrous, yellowish-orange with few small hairs; seven promarginal teeth and 12 basomesal teeth in two curved lines; rastellum on low mound, consists of 28-30 short thick spines, several normal pointed thin spines on dorsal and vertical face and upward.

Labium (Fig. 9): 0.34 wide, 0.20 long. Labiosternal groove shallow, broad with two indistinct sigilla on either side. Cuspules absent.

Maxillae (Fig. 9): 0.98 long in front, 1.24 long in back, 0.72 wide; two equal-sized cuspules on inner angle. Posterior heel slightly produced, anterior lobe distinct, anterior angle curved, posterior edge clear.

Sternum (Fig. 9): 2.02 long, 1.46 wide, covered with bristles and hairs. Sigilla, three pairs, all marginal.

Legs: Uniformly reddish-brown, moderately covered with bristles and hairs; femora III thicker than rest; all legs of similar thickness; preening comb on retroventral metatarsi III and IV; coxae IV widest; two longitudinal glabrous bands on femora, patellae and tibiae (very prominent on patellae); leg formula 4123.

Spines: Leg III: mt, p 2, v 6, r 2, d 1; pa, p 2; leg IV: ti, v 4; mt, p 2, r 2, v 5 . Elsewhere absent.

Scopula: mt I, 2/3 distal with few bristles dividing at base; ta I, full, division with two rows of hairs in distal half; $\mathrm{mt}$ II, $1 / 3$, division with two rows of setae; ta II, full divided with two rows of hairs in distal half, basal half with hairless band; mt III, 2/3 distal, rudimentary, divided with 3-4 rows of spines; ta III, full, divided with 5-7 rows of small setae; $\mathrm{mt} \mathrm{IV,} \mathrm{1/4}$ few scopuliform hairs distally, divided by 3-4 rows of setae; ta IV, full, divided with 5-8 rows of setae.

Trichobothria: ta: I, six clavate, 9-10 long and short filiform in two rows in distal half; II, five clavate, 10 long and short filiform in two rows distal half; III, six clavate, 9-10 long filiform in distal half in two rows; IV, 5 clavate, 9-10 long filiform in distal half in two rows. Clavate trichobothria confined to basal $1 / 4$ of ta.

Claws: Claw tufts present on all legs and palp. Paired edentate claws on all legs, claws of legs I, II clearly smaller than on legs III, IV.

Abdomen (Figs. 8, 9): Dorsally dark brown with faint cream spots/blotches running from dorsal to lateral, uniformly covered with short brown hairs intermixed with few black bristles; ventral side, uniformly dull cream, covered with short and long brown hairs.

Spermathecae (Fig. 12): Two stalks, each stalk with a pair of balloon-like structures of similar length at $2 / 3$ distal end, outer lobe balloon-shaped with constriction at base (Fig. 5). Outer lobe extends well above stalk.

Spinnerets: PMS absent. PLS, apical segment dome-shaped. Covered with golden brown hairs.

\section{Natural history}

Only a single female was found under a small shrub along a tarred road bordering a tea estate in Kotagiri, Nilgiri District, Tamil Nadu. Another empty burrow was found about $5 \mathrm{~mm}$ from the female holotype's burrow. The soil was loose without rocks. The burrow had a single entrance with a diameter of $10.98 \mathrm{~mm}$ at the entrance and was ca. $65 \mathrm{~mm}$ deep. The diameter of the door was 10.14 and $1.14 \mathrm{~mm}$ thick. The base of the burrow was bulb-like. The female was found with an empty egg sac from which spiderlings had hatched and dispersed. Despite rigorous attempts, only two burrows and a single specimen were found. 
Tigidia rutilofronis sp. nov. Sanap, Mirza \& Siliwal (Image 4; Figs. 13-17; Table 3)

\section{Type specimens}

Holotype: Female, 30.i.2011, $11^{0} 1^{\prime} 6.24^{\prime \prime} \mathrm{N}$, \& 76052'29.10”'E, 420m, Marudhamalai, Coimbatore District, Tamil Nadu, India, coll. Rajesh Sanap and Zeeshan Mirza, WILD-11-ARA-1111.

Paratype: One female (WILD-11-ARA-1112), same data as holotype.

\section{Diagnosis (female)}

Females resemble those of $T$. sahyadri sp. nov. and T. nilgiriensis sp. nov. in the number of cuspules on the maxillae and the rastellum consists of numerous spines but differs from T. majori by having only two cuspules on the maxillae (T. majori has ca. 10 cuspules), the rastellum consists of numerous spines (cf. T. majori with a single spine and T. mauritiana with only two spines); it differs from other T. sahyadri sp. nov. and $T$. nilgiriensis sp. nov. in having the balloon-like lateral lobe emerging at the base about $1 / 4$ on the main lobe (in T. sahyadri sp. nov. lateral lobe sickle shape, emerging almost near the apex $3 / 4^{\text {th }}$ of the main lobe with a

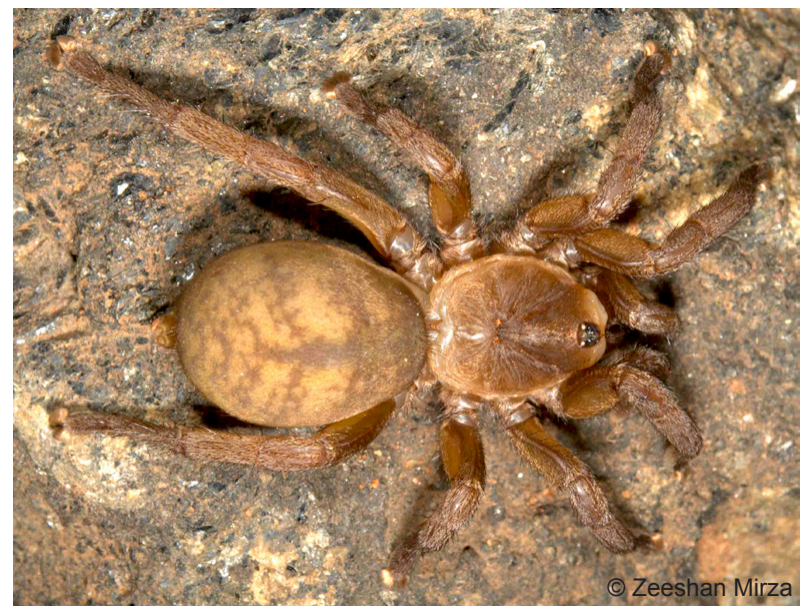

Image 4. Tigidia rutilofronis sp. nov.

distinct constriction at the base; in T. nilgiriensis sp. nov. lateral lobe of spermathecae, balloon-shaped at $2 / 3$ distal end with constriction at base).

\section{Etymology}

The species name is a combination of two latin words, 'rutilus' meaning golden and 'frons' meaning brown referring to the golden brown colouration of the spider in life.
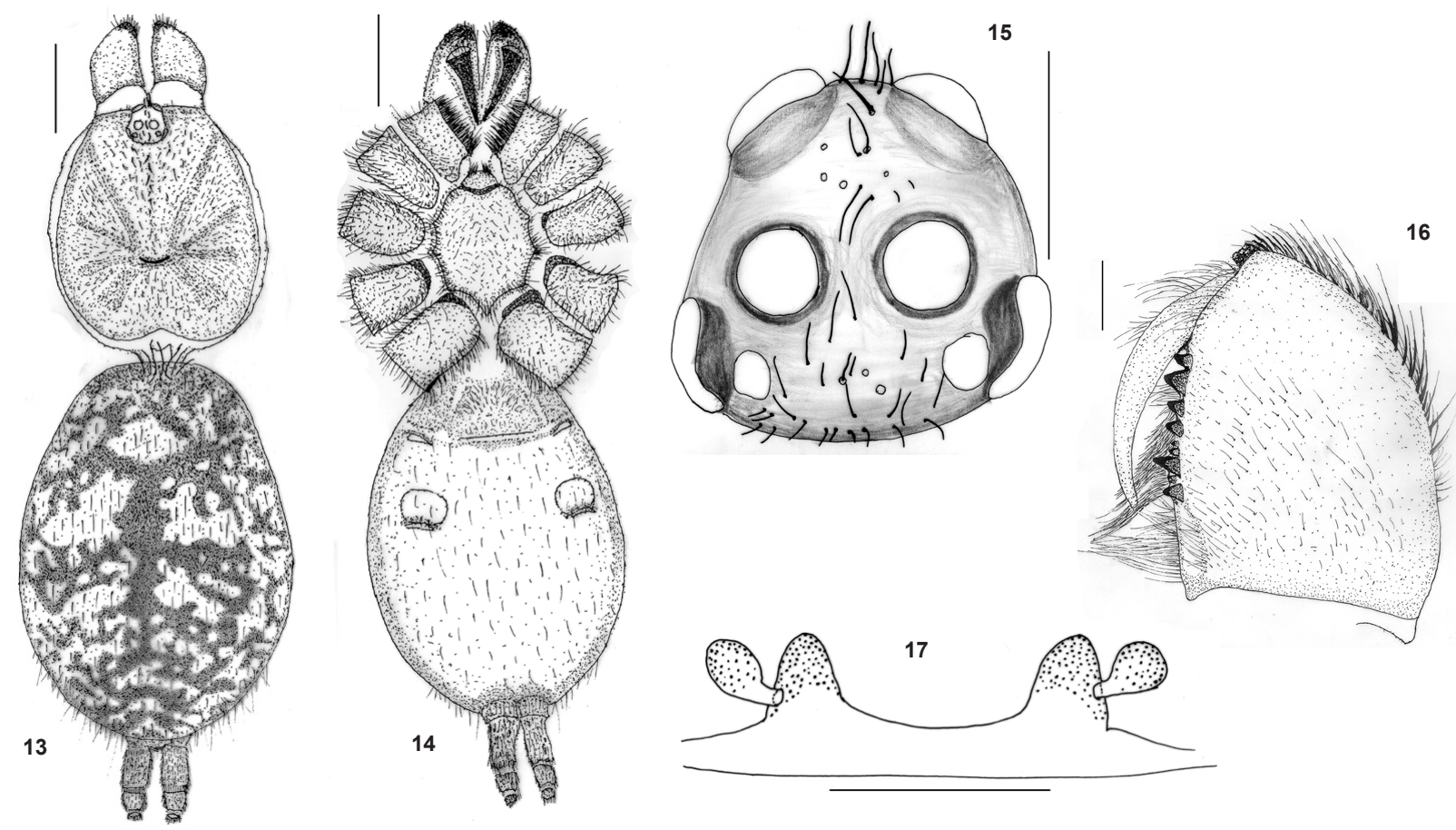

Figures 13-17. Tigidia rutilofronis sp. nov. female holotype (WILD-11-ARA-1111)

1 - Carapace and abdomen, dorsal view (scale=5.0mm); 2 - Sternum, labium, maxilla and abdomen, ventral view (scale=5.0mm); 3 - Eyes $($ scale $=1.0 \mathrm{~mm}) ; 4$ - Chelicerae, prolateral view $($ scale $=1.0 \mathrm{~mm}) ; 5$ - Spermathecae $($ scale $=1.0 \mathrm{~mm})$ 


\section{Description of holotype female}

Total length 22.76. Carapace 8.44 long, 7.06 wide. Abdomen 14.32 long, 9.54 wide. Spinnerets: PLS, total length 2.60 ( 1.50 basal, 0.72 middle, 0.38 apical; midwidths $0.96,0.70,0.42$ respectively), 0.40 apart. Legs and palp morphometry is provided in Table 3.

Colour in life (Image 4): Carapace, legs and palp yellowish-brown. Abdomen yellowish-brown with faint brown chevron markings extending dorsally to laterally giving a lustrous golden sheen (Fig. 13). Venter uniformly yellowish-brown without any pattern (Fig. 14). Colour in alcohol paler than fresh specimen and chevron markings more distinct dorsally and laterally on abdomen.

Carapace covered with golden-brown curved hairs; hairs more concentrated along interstrial ridges intermixed with black short and long bristles on caput. Bristles: two foveal; 17 on caput in mid-dorsal line; seven long, 12 short between posterior eyes; five long, nine short between anterior eyes; four long and short on clypeus edge. Fovea deep, procurved with curved ends.

Eyes (Fig. 15): Ocular group front width 0.96, midwidth 0.94 , back width 1.32 , length1.32. Anterior row strongly procurved, posterior row straight, PME opaque, rest transparent. MOQ front width 0.66 , back width 0.72 , length 0.60 . Diameter of AME 0.18, ALE 0.24, PME 0.08, PLE 0.24. Eye interspaces: AMEAME 0.18, AME-ALE 0.28, ALE-ALE 0.22, PMEPLE adjacent, PME-PME 0.46, ALE-PLE 0.36.

Chelicerae (Fig. 16): 4.84 long. Retrolateral face glabrous, prolateral face yellowish-orange with few short hairs; nine promarginal teeth and 22 basomesal teeth in four curved lines; rastellum on low mound, consists of 27-29 short, thick spines, several normal pointed thin spines on dorsal and vertical face and upward.

Labium(Fig. 14): 1.12 wide, 0.62 long. Labiosternal groove shallow, broad with two sternal sigilla on either side. Cuspules absent.

Maxillae (Fig. 14): 2.02 long in front, 2.70 long in back, 1.38 wide; two cuspules on inner angle. Posterior heel slightly produced, anterior lobe distinct, posterior edge distinct, anterior edge straight.

Sternum (Fig. 14): 4.08 long, 3.06 wide, covered with bristles. Sigilla, three marginal pairs.

Legs: Uniformly yellowish-brown, moderately covered with bristles and hairs; femora III thicker than rest; all legs of similar thickness; preening comb spines on metatarsi III and IV; coxae IV widest; 2 longitudinal glabrous bands on femora, patellae and tibiae (very prominent on patellae); leg formula 4123.

Spines: Leg III: $\mathrm{mt}, \mathrm{p} 2+1$ broken, $\mathrm{v} 2+1$ broken, r 1, d 1; ti, p 2, r 1, v $3+1$ broken pa, p 2; leg IV: ti, p $2+1$ broken, r 2, v 4; mt, p $3+1$ broken, r 1, v 5, d 1 . Elsewhere absent.

Scopula: Mt I, 3/4 distal with few bristles dividing at base; ta I, full, division with 1 row of hairs in distal

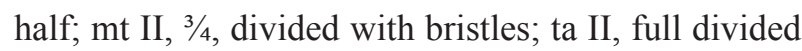
with one row of hairs in distal half, basal half with hairless band; $\mathrm{mt}$ III, 1/2 distal, divided with 6-7 rows of spines; ta III, full, divided with $6-7$ rows of small setae; $\mathrm{mt} \mathrm{IV}, 1 / 4$ distally, divided by $3-4$ rows of setae; ta IV, full, divided with 6-7 rows of setae.

Trichobothria: ta I: 10-11 clavate, 13-14 long and short filiform in two rows in distal half; II: 8-9 clavate, 15-16 long and short filiform in two rows distal half; III: six clavate, 12-13 long filiform in distal half in two rows; IV: eight clavate, 13-14 long filiform in distal half in two rows. Clavate trichobothria confined to basal $1 / 4$ of tarsi.

Claws: Claw tufts on all legs and palp. Paired edentate claws on all legs, claws of legs I and II clearly smaller than on legs III and IV.

Abdomen (Figs. 13, 14): Golden-yellow with brown chevron mark dorsolaterally, uniformly covered with short, brown hairs intermixed with few black bristles; venter yellowish-cream, uniformly covered with short and long brown hairs.

Spermathecae (Fig. 17): Two lobes, main lobe short, slightly broader at base, with lateral balloon-like lobe emerging at base about $1 / 4$ on main lobe, lateral lobe with distinct constriction at base.

Spinnerets: PMS absent. PLS, apical segment dome-shaped. Covered with golden brown hairs.

\section{Morphometry of female paratype}

Total length 11.36. Carapace 5.12 long, 4.12 wide, chelicerae 3.30 long. Sternum, 1.86 long, 1.78 wide. Labium 0.30 long, 0.62 wide. Maxillae 1.26 back length, 1.04 front length, 0.80 wide, 4 cuspules in anterior corner. Abdomen 6.24 long, 4.06 wide. Spinnerets: PMS, absent; PLS, 0.90 basal, 0.40 middle, 0.20 distal, 1.50 total length, midwidths 0.48 , $0.42,0.18$, respectively, 0.44 apart. 


\section{Natural history}

Tigidia rutilofronis sp. nov. was found along a dry rivulet on the sloping bunds bordering the water course near Marudhamalai hills, Coimbatore District in Tamil Nadu. Their distribution was patchy and they were sampled from under trees or in the tree's root system. The diameter of the burrow entrance of the holotype female was $15 \mathrm{~mm}$ and the burrow was ca. $200 \mathrm{~mm}$ deep, as found in other species of this genus and other barychelids in general. The burrow had a single trapdoor entrance similar to trapdoors of the genus Idiops and the burrow end was bulb-like. The soil was sandy and soft at the collection site. The silklining of the burrow was not as thick as observed in other trapdoor families but was similar to that of the theraphosid spider Haploclastus validus Pocock, 1899 as seen at ZM and RS (personal observation). The spiders hid in the burrow until the entire burrow was excavated. The type locality is heavily disturbed and is under severe threat from sand mining.

\section{DISCUSSION}

The preening comb is considered an important generic character to distinguish Tigidia from Diplothele. However, Siliwal et al. (2009) reported a preening comb in Diplothele (D. gravelyi Siliwal et al., 2009; D. tenebrosus Siliwal et al., 2009 and D. walshi O. Pickard-Cambridge, 1890). After examining the preening comb on the Tigidia specimens from the present study, it was very clear that the report of preening combs in Diplothele spiders from Orissa by Siliwal et al. 2009 was erroneous. This also supports the generic character that the preening comb is absent in Diplothele (Raven 1985).

The genus Tigidia presumably evolved in isolation after the breakup of the Indo-Madagascar plate from Africa and during the northward drift gained preening combs which were lost in Diplothele after the breakup of India from Madagascar during the Cretaceous era. Based on preliminary cladistic analysis with reference to characters discussed in Table 1, it is hypothesized that the genus Pisenor is ancestral to the genera Diplothele and Tigidia (Fig. 18).

This report of the genus Tigidia in India adds another member to the list of Gondwanan relics. The present discovery also strongly indicates that though

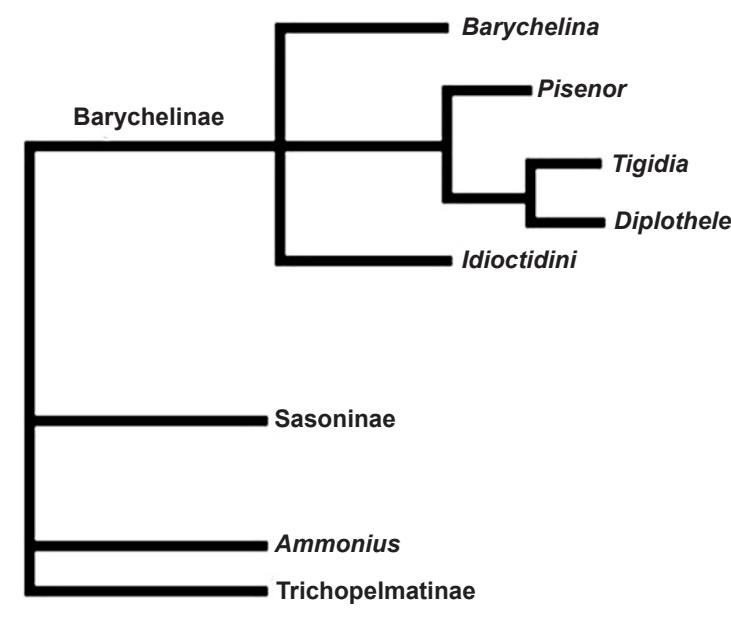

Figure 18. Cladogram showing relative position of the Pisenor, Tigidia and Diplothele in the family Barychelidae

the Western Ghats have been well studied as far as large-bodied spiders like theraphosids are concerned, there is a large scope for finding other new and interesting spiders from this area.

\section{REFERENCES}

Benoit, P.L.G. (1965). Les Barychelidae-Diplothelinae africains et malgaches (Araneae-Orthognatha). Revue de Zoologie et de Botanique Africaines 72: 25-40.

Daniels, R. (2003). Biodiversity of the Western Ghats: An Overview, pp. 25-40. In: Gupta, A.K., A. Kumar \& V. Ramakantha (ed.). ENVIS Bulletin: Wildlife and Protected Areas, Conservation of Rainforests in India. Wildlife Institute of India, Dehradun.

Datta-Roy, A. \& P.K. Karanth (2009). The Out-of-India hypothesis: What do molecules suggest? Journal of Biosciences 34(5): 687-697.

Dippenaar-Schoeman, A.S. (2002). Baboon and Trapdoor Spiders of Southern Africa: An Introduction Manual. Plant Protection Research Institute Handbook No. 13.

Kunte, K. (in press). Biogeographic origins and habitat use of the butterflies of the Western Ghats, south-western India. Invertebrates in the Western Ghats - Diversity and Conservation. D.R. Priyadarshan, K.A. Subramanian, M. S. Devy and N.A. Aravind. Bengaluru, Ashoka Trust for Research in Ecology and the Environment.

Mirza, Z. \& R. Sanap (2010). Description of a new species of scorpion of the genus Lychas CL Koch, 1845 (Scorpiones: Buthidae) from Maharashtra, India. Journal of Threatened Taxa 2(4): 789-796.

Myers, N., R.A. Mittermeier, C.G. Mittermeier, G.A.B. Da Fonseca \& J. Kent (2000). Biodiversity hotspot for conservation priorities. Nature 403: 853-858.

Platnick, N.I. (2011). The World Spider Catalog, Version 12.0. 
American Museum of Natural History, online at http://research.amnh.org/iz/ spiders/catalog. Downloaded on 28 July 2011.

Raven, R.J. (1985). The spider infraorder Mygalomorphae (Araneae): cladistics and systematics. Bulletin of the American Museum of Natural History (USA), 1-180pp.

Raven, R.J. (1994). Mygalomorph spiders of the Barychelidae in Australia and the Western Pacific. Memoirs of the Queensland Museum 35(2): 291-706.

Siliwal, M., S. Molur \& R. Raven (2009). Two new species of the genus Diplothele (Araneae, Barychelidae) from Orissa, India with notes on D. walshi. Journal of Arachnology 37(2): 178-187.

Simon, E. (1892). Etudes arachnologiques. 24e Mémoire. XXXIX. Descriptions d'espèces et de genres nouveaux de la famille des Aviculariidae (suite). Annales de la Société entomologique de France 61: 271-284.

Acknowledgment: Authors (MS and NG) are grateful to the following personnel and institutions: PCCF, Karnataka Forest Department for giving permission and logistic help during the surveys: Mr. Sunil Kumar, Deputy Conservator of Forest, Dandeli WLS, and Mr. R. Gokul, Conservator of Forests, Karwar Division for the logistic support and help during the surveys; Mr. Ramesh and $\mathrm{Mr}$ Suraj Chauhan for assisting in field during the surveys; CEPF (Critical Ecosystem Partnership Fund) -ATREE (Ashoka Trust For Research In Ecology And The Environment) Western Ghats Small Grants Program for funding the tarantula project during which the first specimen of Tigidia was found; Dr. Peter Jäger, Senckenberg Museum, Frankfurt, for providing valuable old reprints on this group of spider; Dr. Sanjay Molur and Ms. Sally Walker, Zoo Outreach Organization for their support and encouragement of the Indian tarantula project; Dr. Bilal Habib, Wildlife Institute of India for helping in scanning drawings. RR wishes to thank curators, Michel Hubert, the late Dr Jacqueline Heurtault and Dr Christine Rollard of Muséum national d'Histoire Naturelle de Paris for loans, access to collections and wonderful cooperation. Some of the information used in this work was obtained by MS on a trip to Australia funded partially by Australian Biological Resources Study grant research funds. NG wishes to deeply thank Dr. Sanjay Keshari Das, Assistant Professor, Guru Gobind Singh Indraprastha University, Delhi for all the encouragement and support he provided as a supervisor for the Masters dissertation during which this spider was found. RS and ZM wish to thank Mr. N.S. Achyuthan and Mr. Gavin Desouza for their continued support during the field and lab work. We pay our deepest gratitude to Achyuthan's family for making our stay comfortable in Coimbatore and making our field visits possible. ZM and RS wish to thank Agarwal Jan Seva Charitable Trust for help with procuring equipment. ZM wishes to thank Bhavan's College for constant encouragement and support.
Author Details and Contribution:

MANJU SILIWAL has been working on spiders since 1997. She has specialized on taxonomy of primitive spiders (mygalomorphs including tarantulas) and has described many new species from India. Her main interest lies in taxonomy, ecology and conservation of Indian spiders. Her contribution to this paper is in identifying the species and preparing the manuscript including taxonomy of first species and refining descriptions of other two species. NEHA GuPTA is MSc in biodiversity and conservation and is very much interested in ecology and conservation of Indian spiders. For her M.Sc. dissertation, she worked on the ecology of trapdoor spiders of the family Idiopidae in Uttara Kannada, Karnataka. She found the first specimen of Tigidia from the Western Ghats. She also assisted in finalizing illustrations and text.

RAJESH SANAP is a graduate student interested in the study of mygalomorphs spiders and scorpions. He has described new species of scorpions and trapdoor spiders. His contribution in this paper is in finding the two species of Tigidia from the Western Ghats. He also contributed to this paper in morphometry, preparing illustrations of the latter two species.

ZeEshan MIRZA is a student of Bhavan's College, Mumbai currently persuing his Bachelors degree in Zoology. He is interested in the study of herpetofauna of the Western Ghats, scorpions and mygalomorph spiders. His contribution to this paper is in the description of latter two species and finalizing the text.

ROBERT RAVEN is world renowned expert on primitive spiders (mygalomorphs) and has experience of about 40 years in spider taxonomy. $\mathrm{He}$ has described 42 genera and 351 species till date from different parts of the world, predominantly from Australia. His contribution to this paper was in finalizing the text, working on language of the paper, reviewing the taxonomy of the species and providing critical inputs on various genera of barychelids including Tigidia. 